DOI: https://doi.org/10.32839/2304-5809/2021-3-91-51

UDC 347.78 .034

Shchypachova Daria

National Technical University of Ukraine

"Igor Sikorsky Kyiv Polytechnic Institute"

\title{
STYLISTIC AND GRAMMATICAL FEATURES \\ OF THE ENGLISH SCIENTIFIC TECHNICAL TEXT AND TRANSLATION
}

Summary. The article deals with the research of stylistic and grammatical features of the English scientific and technical text and its translation. The article reveals the meaning of the concept of "scientific and technical text", which occupies a special place in social communication, as well as highlights the stylistic features of scientific and technical text. Their nomenclature is mainly developed universally at the level of functional styles. But the scientific and technical text, in comparison with other styles, is characterized by obviously expressed differences between its individual genres, namely, the genre specificity is reflected in varying degrees in the depiction of stylistic features. In the course of research characteristic features of the scientific and technical text were allocated. The article notes that the determination and consideration of grammatical and stylistic features of scientific and technical text in the process of translating information of the text, translated from English into Ukrainian and vice versa, allow to correctly perceive this information, accurately express the views of researchers and scientists. The basic requirements that a technical translation must meet have been identified.

Keywords: scientific and technical translation, applied discipline, stylistics, emotionality, terms, typology of the text, literary translation, style.

Щипачова Д.С.

Національний технічний університет України «Київський політехнічний інститут імені Ігоря Сікорського»

\section{СТИЛІСТИЧНІ ТА ГРАМАТИЧНІ ОСОБЛИВОСТІ АНГЛІЙСЬКОГО НАУКОВО-ТЕХНІЧНОГО ТЕКСТУ ТА ПЕРЕКЛАД}

\begin{abstract}
Анотація. Стаття присвячена дослідженню стилістичних та граматичних особливостей англійського науково-технічного тексту та його перекладу. Стаття розкриває зміст поняття “науково-технічний текст”, яке займає особливе місце в соціальній комунікації, а також виокремлюе стильові риси науково-технічного тексту. Їх номенклатура в основному розробляється універсально на рівні функціональних стилей. Але науково-технічний текст, у порівнянні з іншими стилями, характеризуеться яскраво вираженими відмінностями між його окремими жанрами, а саме жанрова специфіка знаходить своє відображення в різній мірі зображення стильових рис. В процесі дослідження були виділені характерні особливості науково-технічного тексту. В статті відзначається, що визначення та врахування граматичних та стилістичних особливостей науково-технічного тексту в процесі перекладу інформації тексту, що перекладаеться з англійської мови на українську і навпаки, дозволяють правильно сприймати цю інформацію, точно виражати думки дослідників та вчених. Були визначені основні вимоги, яким повинен відповідати технічний переклад.
\end{abstract}

Ключові слова: науково-технічний переклад, прикладна дисципліна, стилістика, емоційність, терміни, типологія тексту, художній переклад, стиль.

$\mathrm{P}$ roblem statement. Currently, there is a need to identify scientific technical translation not only as a special type of translation activity and special theory investigating this type of activity, and also conferring the status of an independent scientific and technical translation applied discipline. From the point of view of linguistics, the characteristic features of scientific and technical literature apply to its stylistics, grammar and vocabulary [1]. The main task of scientific and technical translation is extremely clear and accurate rendering of reported information to the reader. This is achieved by a logical rendering of factual material, without explicitly expressed emotionality. The style of scientific and technical literature can be determined as a formal logical one. Scientific and technical texts reveal a number of grammatical features. The most typical lexical feature of scientific technical literature is the richness of the text with terms and terminological phrases, as well as the presence of lexical constructions and abbreviations. In such literature texts, aimed not so much at native speakers of a particular language, but at many representatives of a certain professional group with certain extralinguistic knowledge, occupy a special place.

The object of the study are the problems that arise when the text is translated from English into Ukrainian. The subject of the study is the lexical, grammatical and stylistic features of the translation of the English text.

Recent research and publications. Before starting work, a translator using text analysis should establish which of the types of text he has to translate [4]. Likewise when evaluating a translation, first of all, it is necessary to obtain a clear idea of what type of text the original belongs to, so that avoid the danger of evaluating the translation according to the wrong criteria. Typology of texts that meets the requirements of the translation process and that is distributed for all types of texts encountered in practice is a necessary condition for an objective assessment of translations [3]. There are a number of attempts to develop a typology of texts that would allow drawing conclusions on the principles of translation or on the choice 
of special translation methods. In that there is an understanding that translation methods are determined not only by the circle of readers and the special purpose of the translation. Research into translation problems takes into account the fundamental distinction between pragmatic and literary translation. In pragmatic texts, language is primarily a means of communication, a means of transmitting information, while in texts of artistic prose or poetry, it serves as a means of artistic embodiment, the bearer of the aesthetic significance of the work. Pragmatic texts have a lot in common, it is definitely necessary to take into account whether there is translation and evaluation of translation of specification goods, legal document or philosophical research.

On the other hand, and in literary translation, along with the general factors, there are numerous differentiating factors: the translation of a stylistically "polished" essay is determined by other laws, rather than a translation of a lyric poem. When translating plays it is necessary to follow requirements that are generally not subject to accounting for others types of so-called literary translation.

There are three types of texts [5]:

1) technical and natural science texts characterized by the fact that the knowledge of the subject is more important than knowledge of the language, which, in turn, must first of all extend to knowledge of special terms;

2) philosophical texts, in which, in addition to knowledge of special terminology, the translator is required to be able to follow the course the author's thoughts;

3) literary texts in which, in addition to the content, the identification of subject and art form is necessary, which must be recreated in the language translation.

The classification is also based on differences of material to be translated [1]:

1) informational texts, documentary texts (trade and business) and scientific texts;

2) socio-political texts (including the work of the classics of Marxism, editorials and speeches);

3) (artistically) literary texts.

A common characteristic of the first group of texts is the presence of special terms and special phraseology. The most important requirement for the adequacy of the translation is the requirement of choice of the translator of the most discreet, not distracting from the content syntactic constructions of written speech. When the author's style statements are not essential, then only the subject of the message is taken into account, and not the way of presentation. It seems especially important, however, not found nowhere else an indication of the need to own differentiated special phraseology, without which any translated text must be recognized as of insufficient quality, because to the reader of the translation text it will seem unnatural, or, at least unprofessional.

A common characteristic of the second group of texts of socio-political mixing of scientific elements (using terminology) and artistic language (the use of rhetorical figures, metaphors, etc.). Social and political texts should be classified as either pragmatic, in cases where the foreground is the transfer of information, or to literary and artistic texts, when, with the help of artistic means of language, a certain aesthetic impact, which, of course, must be preserved in translation. This group should not be considered an independent type of text, but, intermediate form, which is a consequence of the ubiquitous intertwining of various types of texts.

The third group of texts is fiction, characterized stylistically by a variety of lexical (dialectal, professional, archaic, exotic) and syntactic linguistic means, as well as the intensive use of elements of colloquial speech.

The characteristic can be extended to other types of texts, for example, for press comments not related to literary texts of artistic type, it seems too one-sided and highlighting only minor points, and most importantly the prevalence aesthetic aspects in the language expression of these texts and the need to preserve their aesthetic value in translation not mentioned at all. The translation method must match the type text. So that the classification of the text is carried out by assigning specific text to a particular type to which this or different translation method. At the same time, the main goal is to preserve the most essential, defining the type of text. Only a special purpose, which translation should serve in a particular case, or the specificity of the circle readers to whom it is intended may be a rationale for deviations from this requirement. But this kind of digression already concerns not translations of the "usual" type, but other forms of transferring content, stated in the source language, into the text in the target language.

Presentation of the main material. Many common characteristics of the scientific and technical style, noted by us in English are also present in scientific and technical materials in Ukrainian. This primarily applies to informativeness of the text and the associated richness of terms and their definitions, to a standard and consistent manner of presentation, its nominal character - the predominance of combinations, the core of which is noun, especially various kinds of attributive groups, relatively wider use of abstract and general words-concepts, the prevalence of phraseological equivalents of the word and semi-terminological stamps.

Scientific and technical materials of the English language are characterized by the predominance of simple sentences, which are on average over $50 \%$ of the total number of sentences in the text. At the same time, the number of complex ones offered are relatively small. This phenomenon is an unusual appropriate style in the Ukrainian language, where complex sentences are used very widely. In this regard, in the English-Ukrainian technical translations one often uses the technique of combining sentences, as a result of two or more simple sentences of the English original there is one complex sentence in the Ukrainian translation. Let us give an example: Classically, we should expect the stopping voltage to be different for different intensities. Furthermore we should not expect any simple direct dependence of the stopping voltage on the frequency of the light used. - 3 точки зору класичної теорії, можна очікувати, що замикаюча напруга буде різною для різних інтенсивностей, але не буде залежати від довжини світла, що падає. 
Special translation theory describes various forms of stylistic adaptation when translating texts belonging to specific functional style. Similar adaptation is determined not only by the linguistic differences, which were discussed. Stylistic adaptation during translation may be necessary in relation to those stylistic features that are at the same time are found in similar styles of the source and target languages. The same stylistic trait can manifest itself to varying degrees in each of the languages, and its presence in the original does not mean that it can simply be reproduced in the translation text.

Comparative analysis of translations shows that translators regularly carry out stylistic adaptation of the translated text, omitting the emotional and stylistic elements of the original, which seem out of place to them in a "serious" scientific presentation. Such, for example, evaluative epithets like dramatic (ефектний), successful (успішний), excellent (відмінний), often turn out to be redundant in Ukrainian translation: These conclusions, however, raised other uncomfortable questions. Ці висновки, однак, викликали багато питань. Similar tendency is also found in relation to "redundant" imagery: Modern technology is growing at a very rapid rate, and new devices are appearing on the horizon much more frequently. Сучасна техніка розвиваеться настільки швидко, що нові типи приладів з'являються значно частіше, ніж це було раніше. Appear on (our) horizon, appear in our field vision, etc. - all this is possible, but unusually figurative for a Ukrainian scientific text.

The lack of complete coincidence between English and Ukrainian scientific technical styles can also be found in the study of comparative frequency of the use of individual parts of speech in them. For scientific presentation in general, the feature of nominativeness is characteristic, i.e. broader use of nouns than in other functional styles. One and the same feature of the scientific and technical style inherent in both English and Ukrainian languages can be manifested with unequal evidence and expressed in different linguistic means.

The following statements are connected in different ways by logical connection: one statement follows from another, explains it, establishes with it causal, temporal, spatial, etc. relations. This feature is revealed both in the English original and in Ukrainian translation. However, in English, logical connections between individual statements are often found only in their very content and are not particularly expressed. Ukrainian language prefers to use special words and introductory phrases indicating that or another type of communication. Therefore, in translation, similar additional clarifications are missing in the original. Translating unfamiliar unambiguous terms using a dictionary is not a difficulty. The situation is different when one English term corresponds to several Ukrainian ones, for example: switch вимикач, перемикач, комутатор. In this case, the conscious choice of an analog can only be dictated by a good knowledge of the subject.

When translating an English text, the translator must complete and accurately convey the author's thought, putting it into a form inherent in Ukrainian scientific technical style and by no means transferring specific features of the English script. The English text is dominated by personal forms of the verb, while the Ukrainian scientific style is more characteristic by impersonal or vaguely personal phrases. Descriptive English texts often use future tense for expressing ordinary action. Guided by context, such sentences should not be translated by the future, but present tense. In English scientific and technical texts, it is especially common to find passive phrases, while in the Ukrainian language the passive voice is used much less frequently. When translating, therefore, it is necessary to replace passive structures with other means of expression, more characteristic of the Ukrainian language.

Conclusion. As a result of the study of the scientific and technical text, it is possible to make the conclusion that the main stylistic feature of such text is accurate and clear presentation of the material in the complete absence of expressive elements that add emotional richness to speech. In scientific literature there are no metaphors, metonymic transpositions and other stylistic figures which are widely used in artistic works.

For all its stylistic remoteness from lively spoken language, scientific and technical text includes a certain amount of more or less neutral phraseological combinations of technical character.

The main requirements to be met by scientific technical translation are:

accuracy - all provisions interpreted in the original must be set out in translation; conciseness all the provisions of the original should be stated, concise and laconic; clarity - the conciseness of the target language should not interfere the presentation of vocabulary, its understanding; literary - the text of the translation must meet the generally accepted norms of the literary language, without the use of syntactic constructions of the original language. During the study, it can also be highlighted that the features of the scientific and technical text are: abundance with special terms and terminological combinations; the presence of grammatical and lexical structures; discrepancy in the use of similar stylistic features in original and translation; different frequency of use of certain parts of speech. All terms are combined into terminological systems, expressing the concepts of science and technology. Difficulties arising from translation of terms associated with the inherent shortcomings of the existing terminological systems. Among the most significant are the phenomenon of terminological synonyms, homonymy and polysemy, which makes it necessary to use contextual translation, which involves: determining the meaning of the translated term by context; selection of an appropriate contextually equivalent term; creation with the selected contextual equivalent of adequate text.

The translation of a scientific and technical text should, correctly, convey the meaning of the original in a form as close as possible to the form of the original. Derogations must be justified by the peculiarities of the Ukrainian language, style requirements. The translation as a whole should not be literal or free retelling of the original, although elements of both are required are present. It is important to avoid the loss of essential information of the original. 


\section{References:}

1. Vinogradov V.S. (2001) Vvedenie v perevodovedenie [Introduction to the Translation Theory]. Moscow. (in Russian)

2. Kozakova T.A. (2001) Prakticheskie osnovy perevoda [Practical translation fundamentals]. Saint-Petersburgh: Soiuz. (in Russian)

3. Superanskaia A.V., Podolskaiia N.V., Vasilieva N.V. (2003) Obshhaya terminologiya. Voprosy teorii [General Terminology. Theory Questions]. Moscow. (in Russian)

4. Baker M. (2003) In Other Words: a coursebook on translation. London; New York: Routledge, 304 p.

5. Nabokov V. (1960) The Art of Translation. Lectures on Russian Literature. New York, 319 p.

\section{Список літератури:}

1. Виноградов В.С. Введение в переводоведение. Москва, 2001.

2. Казакова Т.А. Практические основы перевода. Спнкт-Петербург : Изд-во Союз, 2001.

3. Суперанская А.В., Подольская Н.В., Васильева Н.В. Общая терминология. Вопросы теории. Москва, 2003.

4. Baker M. In Other Words: a coursebook on translation. London; New York : Routledge, 2003. 304 p.

5. Nabokov V. The Art of Translation. Lectures on Russian Literature. New York, 1960. P. 319. 